Original Article

\title{
EVALUATION OF ANTIOXIDANT ACTIVITY OF MAGNOLOL IN SACCHAROMYCES CEREVISIAE
}

\author{
SUBASRI SUBRAMANIYAN, MADHU DYAVAIAH* \\ Department of Biochemistry and Molecular Biology, Pondicherry University, Pondicherry 605014 \\ Email: madhud14@yahoo.co.in
}

Received: 24 Feb 2018 Revised and Accepted: 08 May 2018

\begin{abstract}
Objective: To investigate the antioxidant activity of magnolol in Saccharomyces cerevisiae (S. cerevisiae) model.

Methods: Antioxidant activity of magnolol was demonstrated in S. cerevisiae using spot assay, colony forming unit (CFU) assay, detection of reactive oxygen species (ROS) by fluorescent microscopy and spectrofluorometer, lipid peroxidation (LPO) and catalase (CAT) assay.

Results: A dose-dependent increase in sensitivity of $\mathrm{S}$. cerevisiae was observed with increase in hydrogen peroxide $\left(\mathrm{H}_{2} \mathrm{O}_{2}\right)$ concentration. At 1.5 mmol concentration of $\mathrm{H}_{2} \mathrm{O}_{2}$, we observed $50 \%$ of cell survivability in $\mathrm{CFU}$ and spot assay results. The sensitivity of $\mathrm{S}$. cerevisiae to $\mathrm{H}_{2} \mathrm{O}_{2}$ was protected by magnolol treatment. In spot assay, magnolol pre-treatment showed the similar growth pattern as that of control and in CFU assay $75 \%$ of survivability was observed. Fluorescence microscopic images and fluorescence intensity levels using $2^{\prime}, 7^{\prime}$-dichlorodihydrofluoresceindiacetate $\left(\mathrm{H}_{2}\right.$ DCFDA $)$ showed less number of fluorescence cells and 1.2 fold decrease in fluorescence intensity in magnolol pre-treated cells. The cellular protection in the cells pre-treated with magnolol followed by $\mathrm{H}_{2} \mathrm{O}_{2}$ was correlated with the decreased LPO and increase in CAT activity was recorded.
\end{abstract}

Conclusion: The result of the present study demonstrates that magnolol protects S. cerevisiae cells from $\mathrm{H}_{2} \mathrm{O}_{2}$ induced oxidant mediated cell death.

Keywords: Oxidative stress, ROS, Polyphenol, Magnolol, Antioxidant

(C) 2018 The Authors. Published by Innovare Academic Sciences Pvt Ltd. This is an open access article under the CC BY license (http://creativecommons.org/licenses/by/4.0/) DOI: http://dx.doi.org/10.22159/ijpps.2018v10i6.25467

\section{INTRODUCTION}

ROS mediated oxidative stress plays a significant role in human health and disease management. ROS are non-stable and highly reactive molecules produced as a by-product of cellular metabolism. These ROS cause damages to macromolecules like protein, lipid, and DNA. Alteration in these molecules are associated with many diseases such as cancer, neurodegenerative disease, cardiovascular disease, rheumatoid arthritis, and aging. Antioxidants produced naturally in the body helps to combat against these ROS. But in diseased condition these antioxidants are not sufficient to detoxify free radicals[1]. Plant phytochemicals possess antioxidant properties play a significant role as therapeutic agent to overcome the oxidative stress induced by ROS. Plant derived phytochemicals such as polyphenols, alkaloids flavanoids, terpenoids, and saponins are gaining much importance in many diseases such as cardiovascular diseases, neurodegenerative diseases and cancers.[2]. Polyphenols are the most abundant antioxidant phytochemical present in fruits, vegetables, red wine and legumes, coffee, and tea. These polyphenols act either by activating the antioxidant enzymes or by scavenging the free radicals. Magnolol is an active polyphenolic compound isolated from Magnolia officinalis ( $M$. officinalis) a Chinese plant[3]. It possess various medicinal properties includes antioxidant, anticancer, antiinflammatory and antimicrobial without any toxicity[4]. Antioxidant property of magnolol is due its chemical structural features, biphenyl structure substituted with an allyl group. In spite of extensive studies on the antioxidant property of magnolol in vitro, the molecular mechanism how it works in vivo remains unclear therefore, we investigate the antioxidant activity of magnolol in $S$. cerevisiae model. Yeast $S$. cerevisiae is the first eukaryotic organism whose genome has been completely sequenced. About $30 \%$ of the human homolog genes were conserved in yeast. In this study, we demonstrated antioxidant activity of magnolol in $S$. cerevisiae model.

\section{MATERIALS AND METHODS}

The yeast $S$. cerevisiae (BY4741) (MAT $\alpha$ his3 31 :

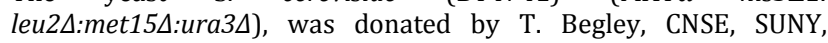
Albany, USA. Yeast strain was routinely grown in YPD medium containing $2 \%(\mathrm{w} / \mathrm{v})$ bacteriological peptone, $1 \%$ yeast extract, $2 \%$ glucose. Magnolol was purchased from Sigma-Aldrich, USA. All other chemicals were purchased from Himedia, India.

Optimization of growth inhibitory concentration of $\mathrm{H}_{2} \mathrm{O}_{2}$ in $S$. cerevisiae

\section{Spot assay}

Exponentially growing $\left(\mathrm{OD}_{600}=0.5\right) S$. cerevisiae cells were 10 -fold serially diluted for five times and spotted on YPD plates containing with or without different concentration of $\mathrm{H}_{2} \mathrm{O}_{2}$. After incubating at $30^{\circ} \mathrm{C}$ for $3 \mathrm{~d}$, plates were imaged using SYNGENE gel doc, USA.

\section{CFU assay}

Exponentially growing $\left(\mathrm{OD}_{600}=0.5\right)$ cells were treated with different concentrations of $\mathrm{H}_{2} \mathrm{O}_{2}$. After $1 \mathrm{~h}$ of incubation in a shaker incubator at $30{ }^{\circ} \mathrm{C}$, cells were serially diluted and spread on to YPD plates. After $3 \mathrm{~d}$ of incubation at $30^{\circ} \mathrm{C}$, the colonies were counted and the results were expressed as percentage of survival in relation to 100 $\%$ growth in untreated control from the average standard deviation of three independent experiments.

\section{Antioxidant activity of magnolol}

Spot assay

Exponentially growing yeast cells were treated with or without magnolol $20 \mu \mathrm{M}$ for $1 \mathrm{~h}$ and then spotted on to YPD plate containing with or without $1.5 \mathrm{mmol} \mathrm{H}_{2} \mathrm{O}_{2}$ [5].

\section{CFU assay}

Exponentially growing yeast cells were treated with or without magnolol for $1 \mathrm{~h}$ and then exposed to $\mathrm{H}_{2} \mathrm{O}_{2}$ for $1 \mathrm{~h}$. Subsequently, cells were serially diluted and plated onto YPD plate and incubated for $3 \mathrm{~d}$ [5].

\section{Detection of ROS level}

Exponentially growing yeast cells were treated with or without magnolol for $1 \mathrm{~h}$ and then exposed to $\mathrm{H}_{2} \mathrm{O}_{2}$ for $1 \mathrm{~h}$. Cells were 
washed with sorbitol buffer ( $\mathrm{pH}$ 7.4) and incubated with $\mathrm{H}_{2}$ DCFDA $(20 \mu \mathrm{M})$ for $30 \mathrm{~min}$ in dark at room temperature. Immediately after incubation, cells were harvested by centrifugation $(5000 \mathrm{rpm}$ for 5 min. at $4{ }^{\circ} \mathrm{C}$ ), and washed thrice with PBS (phosphate buffered saline). The cells were observed under fluorescent microscope and fluorescence intensity was measured using a spectrofluorometer with an excitation wavelength of $485 \mathrm{~nm}$ and an emission wavelength of $525 \mathrm{~nm}$ at fluorescent microplate reader (Molecular Devices, USA) [5].

\section{LPO assay}

Yeast culture was centrifuged, the pellet was washed with PBS twice and re-suspended in a solution containing $0.375 \mathrm{~g}$ TBA (thiobarbituric acid)-15 \% TCA (tricarboxylic acid)-0.25 N Hcl (hydrochloric acid). The cell suspension was vortexed in presence of glass beads for $3 \mathrm{~min}$, short pulses of $1 \mathrm{~min}$ were used with $1 \mathrm{~min}$ intervals on ice. Extracts were centrifuged at $6000 \mathrm{rpm}$ for $3 \mathrm{~min}$, and the supernatant was incubated in a boiling water bath for $15 \mathrm{~min}$. After cooling, the malonialdehyde (MDA) content was measured at $532 \mathrm{~nm}$. Protein content was estimated using Bradford's method [6]. The levels of LPO were expressed as $\mu \mathrm{M}$ of MDA/mg protein [7].

\section{CAT assay}

The treatment and cell pelleting were similar as explained above. The cell extracts were prepared by suspending the cells in lysis buffer ( $50 \mathrm{mmol}$ Tris, $150 \mathrm{mmol} \mathrm{NaCl}, 50 \mathrm{mmol}$ EDTA, and $0.2 \mathrm{mmol}$ phenylmethylsulfonyl fluoride $\mathrm{pH}$ 7.2) with glass beads, vortexed for $10-15$ cycles ( $30 \mathrm{~s}$ each), followed by $30 \mathrm{~s}$ of cooling. The mixture was then centrifuged and the supernatant was taken for CAT assay. CAT activity was determined spectrophotometrically by monitoring the disappearance of $\mathrm{H}_{2} \mathrm{O}_{2}$ at $240 \mathrm{~nm}$. The CAT activity was expressed as $\mathrm{nmol} / \mathrm{mg}$ of protein [8].

\section{Statistical analysis}

Results are reported as means \pm SD of three independent experiments. The values were analyzed by the one way anova (ANOVA). Values of $p<0.05$ were considered to be statistically significant.

\section{RESULTS}

Optimization of $\mathrm{H}_{2} \mathrm{O}_{2}$ concentration to study the antioxidant activity of magnolol

We exposed S. cerevisiae cells to a different concentration of $\mathrm{H}_{2} \mathrm{O}_{2}$. Spot assay results (fig. 1A) showed that the sensitivity of cells increased with increase in $\mathrm{H}_{2} \mathrm{O}_{2}$ concentration. Similar result was also observed in CFU assay where $50 \%$ of survivability was recorded at $1.5 \mathrm{mmol} \mathrm{H}_{2} \mathrm{O}_{2}$ concentration. Therefore, we fixed the concentration at which fifty percent of the cell would survive on $\mathrm{H}_{2} \mathrm{O}_{2}$ treatment to study the antioxidant activity of magnolol.

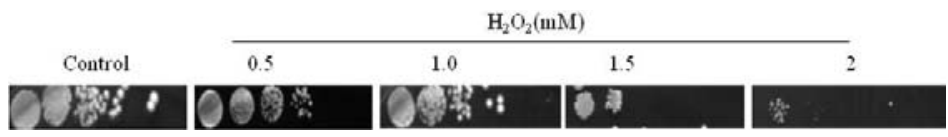

A.

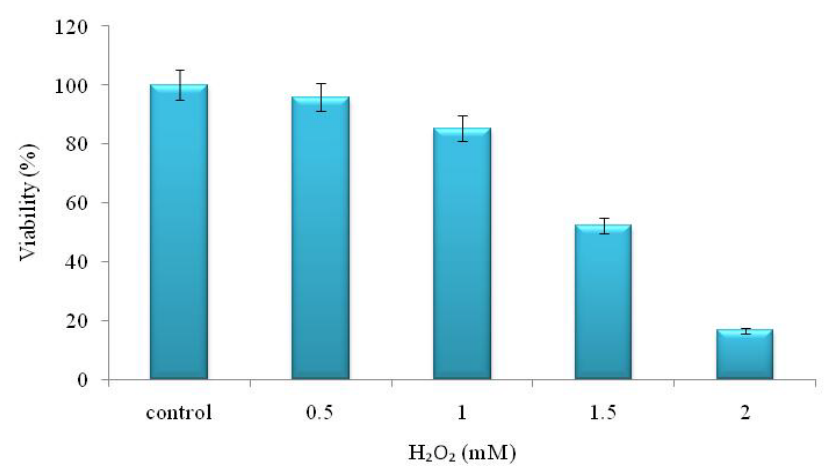

B.

Fig. 1: Effect of $\mathrm{H}_{2} \mathrm{O}_{2}$-induced cell death on $S$. cerevisiae cells A) Spot assay B) Colony forming unit assay. Data are mean \pm SD of three independent experiments

\section{Antioxidant activity of magnolol}

The antioxidant activity of magnolol was tested in S. cerevisiae using spot and CFU assay. In the spot assay, control and magnolol alone treated followed the same growth pattern, whereas $\mathrm{H}_{2} \mathrm{O}_{2}$ treatment resulted in decreased cell survivability when compared to control. In contrast pre-treatment with magnolol protected the cells from $\mathrm{H}_{2} \mathrm{O}_{2}$ stress, and the spots appeared similar to that of control (fig. 2A).

CFU assay was performed to calculate the percentage protection conferred by magnolol on the survival of yeast cells against oxidative stress induced by $\mathrm{H}_{2} \mathrm{O}_{2}$. Yeast cells grown to the exponential phase and pre-treated with or without magnolol for $1 \mathrm{~h}$ and then exposed to $\mathrm{H}_{2} \mathrm{O}_{2}(1.5 \mathrm{mmol})$ for $1 \mathrm{~h}$. The analysis of cell survivability in fig. 2B showed that the treatment with $\mathrm{H}_{2} \mathrm{O}_{2}$ showed decreased (50\%) survivability, whereas magnolol treatment showed increased (75\%) survivability compared to control.

\section{Magnolol scavenge ROS in S. cerevisiae cells}

$\mathrm{H}_{2}$ DCFDA staining was carried out to measure whether the accumulation of ROS induced by $\mathrm{H}_{2} \mathrm{O}_{2}$ and scavenged by magnolol. The fluorescent microscopic images showed that the increases in the number of green fluorescent cells in $\mathrm{H}_{2} \mathrm{O}_{2}$ treated culture were decreased when cells pre-treated with magnolol followed by $\mathrm{H}_{2} \mathrm{O}_{2}$ (fig. 3A). The results obtained by the spectrofluorometer (fig. 3B) showed more fluorescent intensity in $\mathrm{H}_{2} \mathrm{O}_{2}$ treated cells, whereas cells pre-incubated with magnolol showed a 1.2 fold decrease in fluorescence intensity compared to $\mathrm{H}_{2} \mathrm{O}_{2}$ alone treated cells.

\section{Magnolol reduce LPO in S. cerevisiae}

Exposure of yeast cells to $\mathrm{H}_{2} \mathrm{O}_{2}$ showed increased LPO compared to control. In contrast, LPO was decreased significantly in the cells pretreated with magnolol (fig. 4). The result indicated magnolol decreased the constitutive levels of lipid damages and protects cells from $\mathrm{H}_{2} \mathrm{O}_{2}$ induced oxidative stress.

\section{Magnolol induces CAT activity}

We measured the CAT activity to test whether the induction of enzymatic defence contributes to the protective effect of magnolol or it protects cells from scavenging ROS. The results showed that CAT activity was increased in the cells pre-treated with magnolol when compared to $\mathrm{H}_{2} \mathrm{O}_{2}$ treated and control (fig. 5). This result indicated magnolol induce CAT activity in addition to scavenging ROS directly to protect cells from oxidative stress. 


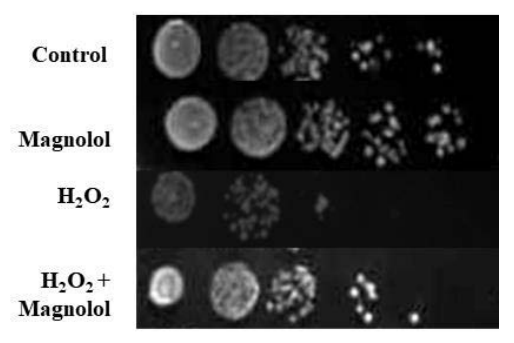

A

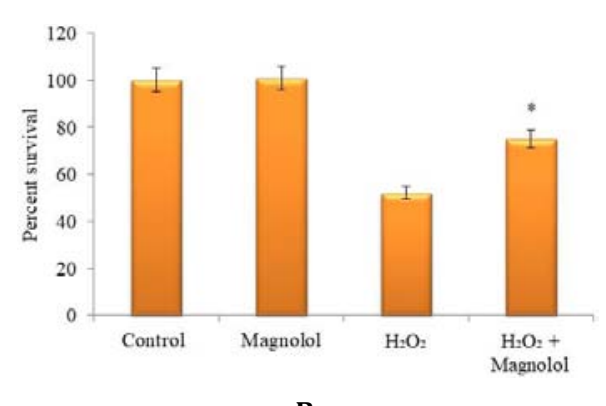

B

Fig. 2: Effect of magnolol on the viability of $S$. cerevisiae cells. A) Spot assay B) Colony forming unit assay, data are mean \pm SD. of three independent experiments. ${ }^{*} p<0.05$

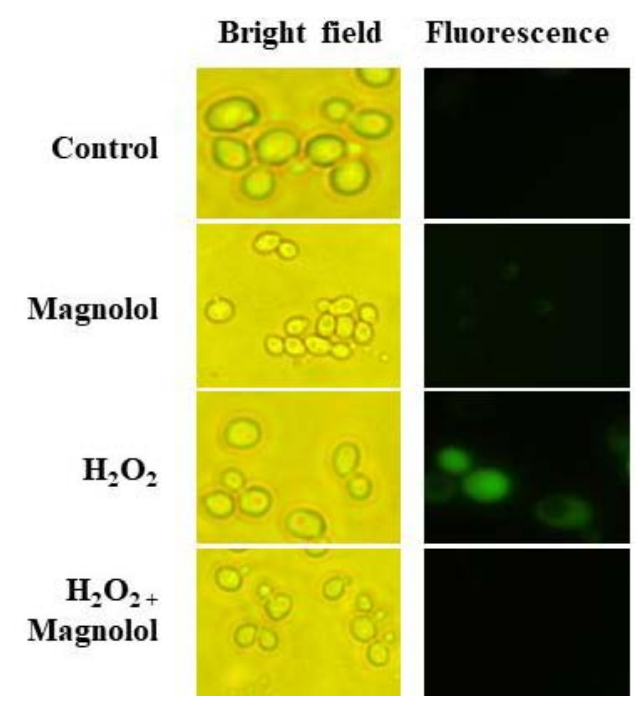

A

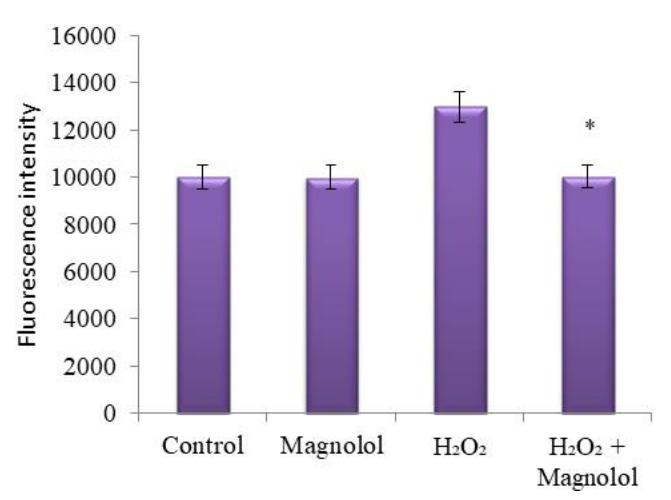

B

Fig. 3: Detection of ROS A) Fluorescent microscopy B) Spectrofluorometer Data are mean \pm SD. of three independent experiments. ${ }^{*} p<0.05$

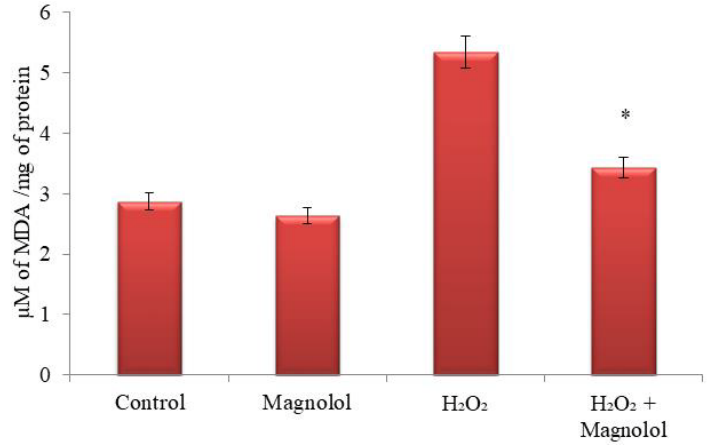

Fig. 4: Effect of magnolol on lipid peroxidation, data are mean \pm SD. of three independent experiments. ${ }^{*} p<0.05$

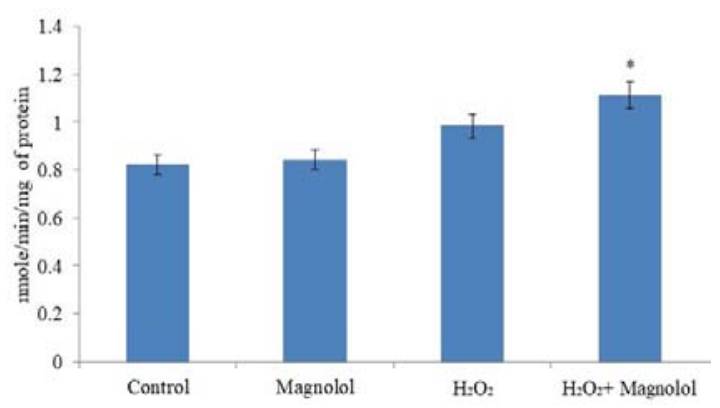

Fig. 5: Effect of magnolol on catalase activity, data are mean \pm SD of three independent experiments. ${ }^{*} p<0.05$

\section{DISCUSSION}

ROS are toxic molecules produced during cellular metabolism and also induced by environmental chemicals and radiation. They act as signalling molecules and also control processes such as cell growth and development. Oxidative stress increases the level of ROS which causes damage to protein, lipid, and DNA that leads to many pathological diseases. To overcome this stress, the biological system has the well-developed antioxidant machinery to scavenge the free radicals. Cells have two antioxidant systems (i) enzymatic antioxidants such as superoxide dismutase (SOD), CAT, glutathione peroxidase (GPX), glutathione reductase (GR) and (ii) non-enzymatic antioxidants like ascorbic acid (AA), reduced glutathione (GSH), and $\alpha$-tocopherol. There will be always equilibrium between oxidant and antioxidant. When ROS exceeds the levels, then cells are said to be under oxidative stress. Plant-derived antioxidants are of great interest to mitigate the oxidative stress induced damages in the cells. Plants are the potential source which help in the management of many diseases through its antioxidant property[9]. In this study, magnolol, a bisphenol compound from $M$. officinalis has been employed to study its antioxidant property in yeast model organism against $\mathrm{H}_{2} \mathrm{O}_{2}$ treatment. $\mathrm{H}_{2} \mathrm{O}_{2}$ is the most toxic free radical generator during cellular metabolism. It generates $\mathrm{OH}$-via Fenton reaction which is highly reactive and damage macromolecules. The results from $\mathrm{H}_{2} \mathrm{O}_{2}$ sensitivity assay showed that $1.5 \mathrm{mmol} \mathrm{H}_{2} \mathrm{O}_{2}$ killed $50 \%$ of yeast cells as shown in CFU assay results (fig. 1B). In the antioxidant protection assay, magnolol pre-treatment rescued the cells from $\mathrm{H}_{2} \mathrm{O}_{2}$ induced sensitivity and showed better cell survivability compared to $\mathrm{H}_{2} \mathrm{O}_{2}$ alone treated cells (fig. $2 \mathrm{~A}$ and $\mathrm{B}$ ) Magnolol pre-treatment reduces the ROS positive cells in $\mathrm{H}_{2} \mathrm{O}_{2}$ treated cultures. These results suggest that the ROS scavenging ability of magnolol protected the cells from oxidative-mediated cell death in S. cerevisiae. Magnolol possesses allyl group, that proved to be an effective hydroxyl radical and superoxide radical scavenger [10]. The protective effect of magnolol correlates with the decrease in intracellular oxidation (fig. 3A and B) and lipid oxidation (fig. 4). Polyphenolic compounds are preferentially incorporated into membrane lipid bilayers and act as hydrogen donors, trapping free radicals and inhibiting the formation of lipid radicals. The decrease in LPO has been associated with hepatoprotective activity [11]. 
Magnolol has been reported to be 1000 times more potent than $\alpha$ tocopherol in reducing the LPO [4] and 340 times inhibiting MDA formation in rat hepatic mitochondria[12]. It protected the sperm motility by decreasing LPO [13]. It also reduced the ROS accumulation in acrolein-induced oxidative stress [14]. Increasing $\mathrm{H}_{2} \mathrm{O}_{2}$ resistance accompanied with decrease of ROS in $S$. cerevisiae was demonstrated using various antioxidants such as propolis [15], lisosan G [16], ginkgo biloba leaf [17], resveratrol [18] and quercetin [19]. The antioxidant enzyme level reflects the anti-oxidation status in yeast. A significant increase in CAT activity in S. cerevisiae cells pre-treated with magnolol (fig. 5), suggesting that magnolol induce CAT activity and that could provide antioxidant protection in the cells against oxidative stress. Studies have shown that magnolol treatment increased the CAT and SOD activity in the Kunming mice [20]. Our study also suggests using yeast as a model organism to study the antioxidant property of a natural compound in vivo.

\section{CONCLUSION}

Magnolol achieved excellent protection against $\mathrm{H}_{2} \mathrm{O}_{2}$ mediated oxidative stress which can be implicated in aging and aging associated diseases in human. Yeast can be used as a prominent model to study antioxidant property of a natural compound.

\section{ACKNOWLEDGMENT}

The authors duly acknowledge UGC-MRP(F NO 42-665/2013 (SR dated 25-03-2013) for providing financial assistance and DST-FIST for infrastructure The first author also acknowledges Pondicherry University UGC, Govt. of India for the BSR-fellowship.

\section{ABBREVIATION}

S. cerevisiae-Saccharomyces cerevisiae, CFU-Colony forming unit, $\mathrm{H}_{2} \mathrm{O}_{2}$-Hydrogen peroxide, ROS-Reactive oxygen species, $\mathrm{H}_{2}$ DCFDA$2^{\prime}, 7^{\prime}$-Dichlorodihydrofluorescein diacetate, DCF-2', $7^{\prime}$ dichlorofluorescein, TBA-Thiobarbituric acid, TCA-Tricarboxylic acid, Hcl-Hydrochloric acid, CAT-Catalase, SOD-Superoxide dismutase, LPO-Lipid peroxidation, MDA-malondialdehyde, GPXGlutathione peroxidase, GR-Glutathione reductase, AA-Ascorbic acid, GSH-Reduced glutathione, PBS-Phosphate buffered saline, $M$. officinalis-Magnolia officinalis

\section{AUTHORS CONTRIBUTIONS}

SS and MD have designed the study. SS performed the experiments. MD and SS drafted and corrected the manuscript.

\section{CONFLICT OF INTERESTS}

We declare that we have no conflict of interests

\section{REFERENCES}

1. Venkatayappa G Reddy. A free radical quenching efficacy of various extracts of Costus pictus to combat oxidative damage/stress: an in vitro study. Asian J Pharm Clin Res 2017;10:178-81.

2. Rajesh KD, Vasantha S, Panneerselvam A, Rajesh NV, Jeyathilakan N. Phytochemical analysis, in vitro antioxidant potential and gas chromatograph Y-mass spectrometry studies of dicranopteris linearis. Asian J Pharm Clin Res 2016;9:220-5.

3. Hong CY, Huang SS, Tsai SK. Magnolol reduces infarct size and suppresses ventricular arrhythmia in rats subjected to coronary ligation. Clin Exp Pharmacol Physiol 1996;23:660-4.
4. Chen YH, Huang PH, Lin FY, Chen WC, Chen YL, Yin WH, et al. Magnolol: a multifunctional compound isolated from the Chinese medicinal plant Magnolia officinalis. Eur J Integr Med 2011;3:e317-24.

5. Alugoju P, Janardhanshetty SS, Subaramanian S, Periyasamy L, Dyavaiah M. Quercetin protects yeast saccharomyces cerevisiae pep4 mutant from oxidative and apoptotic stress and extends chronological lifespan. Curr Microbiol 2017;75:519-30.

6. Bradford MM. A rapid and sensitive method for the quantitation of microgram quantities of protein utilizing the principle of protein-dye binding. Anal Biochem 1976;72:24854.

7. Howlett NG, Avery SV. Induction of lipid peroxidation during heavy metal stress in Saccharomyces cerevisiae and influence of plasma membrane fatty acid unsaturation. Appl Environ Microbiol 1997;63:2971-6.

8. Beers FR, Sizer IW. A spectrophotometric method for measuring the breakdown of hydrogen peroxide by catalase. J Biol Chem 1951;195:133-40.

9. Sutar RC, Kalaichelvan VK. Evaluation of antioxidant activity of leaf extracts of Holoptelea integrifolia (Roxb) planch. Int J Appl Pharm 2014;6:6-8.

10. Ogata M, Hoshi M, Shimotohno K, Urano S, Endo T. Antioxidant activity of magnolol, honokiol, and related phenolic compounds. J Am Oil Chem Soc 1997;74:557-62.

11. Chen YH, Lin FY, Liu PL, Huang YT, Chiu JH, Chang YC. Antioxidative and hepatoprotective effects of magnolol on acetaminophen-induced liver damage in rats. Arch Pharm Res 2009;32:221-8.

12. Chiu JH, Wang JC, Lui WY, Wun WC, Ye HC. Effect of magnolol on in vitro mitochondrial lipid peroxidation and isolated coldpreserved warm-reperfused rat livers. J Surg Res 1999;82:116.

13. Lin MH, Chao HT, Hong CY. Magnolol protects human sperm motility against lipid peroxidation: a sperm head fixation method. Arch Androl 1995;34:151-6.

14. Dong L, Zhou S, Yang X, Chen Q, He Y, Huang W. Magnolol protects against oxidative stress-mediated neural cell damage by modulating mitochondrial dysfunction and PI3K/Akt signaling. J Mol Neurosci 2013;50:469-81.

15. de Sá RA, de Castro FA V, Eleutherio ECA, Souza RM, Silva JFM, Pereira MD. Brazilian propolis protects Saccharomyces cerevisiae cells against oxidative stress. Brazilian J Microbiol 2013;44:993-1000.

16. Frassinetti S, Della Croce CM, Caltavuturo L, Longo V. Antimutagenic and antioxidant activity of lisosan G in Saccharomyces cerevisiae. Food Chem 2012;135:2029-34.

17. Marques F, Azevedo F, Johansson B, Oliveira R. Stimulation of DNA repair in Saccharomyces cerevisiae by Ginkgo biloba leaf extract. Food Chem Toxicol 2011;49:1361-6.

18. Dani C, Bonatto D, Salvador M, Pereira MD, Henriques JAP, Eleutherio E. Antioxidant protection of resveratrol and catechin in Saccharomyces cerevisiae. J Agric Food Chem 2008;56:426872.

19. Belinha I, Amorim MA, Rodrigues P, Freitas VD, Ferreira PM, Mateus N, et al. Quercetin increases oxidative stress resistance and longevity in Saccharomyces cerevisiae. J Agric Food Chem ;2007;55:2446-51.

20. Pang YL, Han XF, Bamikole MA, Gong ZH, Tang SX, Tan ZL, et al. Anti-diarrhea and anti-oxidant properties of Magnolol. Trop J Pharm Res 2013;12:85-91. 